\title{
Herbivores shape woody plant communities in the Kruger National Park: Lessons from three long-term exclosures
}

\author{
Authors: \\ Benjamin J. Wigley ${ }^{1,2}$ \\ Herve Fritz ${ }^{2}$ \\ Corli Coetsee ${ }^{1}$ \\ William J. Bond ${ }^{3}$

\section{Affiliations:} \\ ${ }^{1}$ School of Natural Resource \\ Management, Nelson \\ Mandela Metropolitan \\ University, George campus, \\ South Africa
}

2UMR CNRS 5558 LBBE, University Claude Bernard Lyon 1, France

${ }^{3}$ Department of Biological Sciences, University of Cape Town, South Africa

Correspondence to: Benjamin Wigley

Email:

benjamin.wigley@nmmu. ac.za

Postal address: Private Bag X6531, George 6530 , South Africa

Dates:

Received: 07 May 2013

Accepted: 18 Sept. 2013

Published: 11 Mar. 2014

How to cite this article: Wigley, B.J., Fritz, H., Coetsee, C. \& Bond, W.J. 2014, 'Herbivores shape woody plant communities in the Kruger National Park: Lessons from three long-term exclosures', Koedoe 56(1), Art. \#1165, 12 pages. http://dx.doi.org/10.4102/ koedoe.v56i1.1165

\section{Copyright:}

C 2014. The Authors. Licensee: AOSIS OpenJournals. This work is licensed under the Creative Commons Attribution License.

\section{Read online:}

The role of grazers in determining vegetation community compositions and structuring plant communities is well recognised in grassy systems. The role of browsers in affecting savanna woody plant communities is less clear. We used three long-term exclosures in the Kruger National Park to determine the effect of browsers on species compositions and population structures of woody communities. Species assemblages, plant traits relating to browsing and soil nutrients were compared inside and outside of the exclosures. Our results showed that browsers directly impact plant species distributions, densities and population structures by actively selecting for species with traits which make them desirable to browsers. Species with high leaf nitrogen, low total phenolic content and low acid detergent lignin appeared to be favoured by herbivores and therefore tend to be rare outside of the exclosures. This study also suggested that browsers have important indirect effects on savanna functioning, as the reduction of woody cover can result in less litter of lower quality, which in turn can result in lower soil fertility. However, the magnitude of browser effects appeared to depend on inherent soil fertility and climate.

Conservation implications: Browsers were shown to have significant impacts on plant communities. They have noticeable effects on local species diversity and population structure, as well as soil nutrients. These impacts are shown to be related to the underlying geology and climate. The effects of browsers on woody communities were shown to be greater in low rainfall, fertile areas compared to high rainfall, infertile soils.

\section{Introduction}

The role of herbivory in structuring plant communities and determining community compositions is well recognised (see reviews by Augustine \& McNaughton 1998; Huntly 1991). For example, native ungulate browsers have been found to have major impacts on shrub dynamics in East African savannas (Augustine \& McNaughton 2004). Different feeding behaviours and food preferences of browser species have major impacts on South African (Owen-Smith \& Cooper 1987) and West African savanna woody communities (Jachmann \& Croes 1991). These impacts are often attributed to selective feeding related to food quality (Owen-Smith \& Cooper 1987). As in savannas (e.g. Staver et al. 2009), herbivores have been found to regulate recruitment rate and species composition of trees in temperate forests (Ammer 1996; Kriebitzsch et al. 2000; Van Hees, Kuiters \& Slim 1996) and grassland (Anderson \& Briske 1995).

Many of the studies on browser-plant interactions in savannas have tended to focus on interactions between browsers and specific woody species. For example, Coetzee et al. (2008), Gadd (2002) and Helm and Witkowski (2012) looked at browser interactions with Sclerocarya birrea, whilst Fornara and Du Toit (2007) documented the response of Acacia nigrescens to ungulate browsing. These two species are important browse species in southern African savannas. As savanna woody species tend to be highly variable in form and function, these studies usually do not provide a better understanding of savanna dynamics at the community level. Augustine and McNaughton (2004) emphasised the need for replicated experiments that assess the effects of native browsers on shrub dynamics in African savannas, as our understanding of the importance of browser effects on woody plant dynamics remains unclear. A better understanding of how browsers and woody plants interact at the community level and how these interactions affect savanna dynamics will be invaluable in managing browser populations.

The existence of three long-term herbivore exclosures in the Kruger National Park, South Africa, provides a good opportunity to empirically determine the role of browsers in determining woody species composition and population structures of woody communities growing at the three study sites. Previous studies have shown evidence for taller canopies and higher tree and shrub densities 
inside exclosures at Nhlangwini (Asner et al. 2009; Levick et al. 2010; Trollope et al. 1998), Makhohlola (Levick et al. 2009; Trollope et al. 1998) and N'waxitshumbe (Asner et al. 2009; Levick \& Rogers 2008; Trollope et al. 1998). In these studies, the analyses were generally based on remote sensing and ignored species identity. Differences in woody community compositions and plant traits between exclosure treatments are therefore still largely undocumented.

Differences in species compositions between treatments would be highly informative as the species found inside but not outside, are likely to be vulnerable to herbivory and therefore no longer found outside of the exclosures or found at reduced densities. The traits of these species can be used to provide us with clues as to what makes them vulnerable to herbivory. For example, Díaz et al. (2007) found that at the global scale there is a spectrum of plant responses to herbivory with high levels of herbivory favouring annual over perennial plants, short plants over tall plants, prostrate over erect plants and stoloniferous plants over those with tussock architecture.

This article aims to determine how browsers and plant traits interact and how these interactions affect woody plant population dynamics and community assemblages. We aim to determine if there are differences in species compositions and key plant functional traits between the woody communities found growing inside and outside the three long-term exclosures in the Kruger National Park (KNP). Plant traits are important in determining both the type of and degree of vertebrate herbivory, whilst they also can reflect plant responses to herbivory. We measured a number of plant traits that are likely to impact and respond to browsing; these included leaf nitrogen $(\mathrm{N})$ and phosphorus $(\mathrm{P})$, leaf carbon-nitrogen ratio (C:N), specific leaf area (SLA), leaf size, leaf dry matter content (LDMC), leaf tensile strength, bite size index (BSI) and levels of secondary compounds. High leaf $\mathrm{N}$ and leaf $\mathrm{P}$ are associated with higher nutritional quality for herbivores (Cornelissen et al. 2003). Leaves with lower $\mathrm{C}: \mathrm{N}$ ratios are much more attractive to herbivores as these leaves have higher $\mathrm{N}$ content (Cornelissen et al. 2003). The SLA of a species is usually a good correlate of its potential growth rate. Lower SLA values tend to correspond with relatively high investments in defences, both structural and chemical, and long leaf life span, all of which affect nutritional value (Cornelissen et al. 2003). Environmental nutrient stress and disturbance, as well as phylogenetic factors, play a role in determining leaf size (Cornelissen et al. 2003). Smaller leaves with higher SLA are typically more attractive to herbivores. Leaves with high LDMC values tend to be tough and therefore more resistant to disturbances such as herbivory or wind than leaves with low LDMC. Species with low LDMC are usually associated with productive and highly disturbed areas (Cornelissen et al. 2003). Leaf tensile strength is a good indicator of the relative carbon investment in structural protection of the photosynthetic tissue. Physically stronger leaves are better protected from abiotic (winds, storms) and biotic mechanical damage (herbivory). Higher physical strength usually results in longer leaf span; however, this is usually combined with other physical and chemical defences such spines and tannins (Cornelissen et al. 2003). BSI is a measure of how easily leaves can be browsed by a simulated browser (a human), whilst stem specific density broadly trades off against relative growth rate and stem defences against pathogens, herbivores and mechanical damage (Cornelissen et al. 2003). Condensed tannins and polyphenols are organic $\mathrm{N}$-free chemical defences that bind with protein, reducing $\mathrm{N}$ availability to herbivores, thereby decreasing preference by mammal herbivores (Bergvall \& Leimar 2005; Haslam 1988; Owen-Smith 2005). The concentrations of the cell wall constituents (neutral detergent fibre [NDF], acid detergent fibre [ADF] and acid detergent lignin [ADL]) determine the digestibility of leaf material for herbivores. Detergent analysis has been used to compare fibre digestibility across different plant types (e.g. see Codron et al. 2007 and references therein).

The following questions are specifically addressed using the three exclosures. Firstly, has the long-term exclusion (> 40 years) of herbivores led to differences in woody plant species compositions at the three exclosures? Secondly, do the structures, densities and abundances of the woody species populations differ inside and outside of the exclosures? Thirdly, are there differences in plant leaf and stem traits between the species only found inside versus common species found both inside and outside? Fourthly, has the long-term removal of herbivores from the exclosures had any effects on soil nutrient cycling? Fifthly, do the exclosures help us to predict under what conditions herbivores play an important role in determining the structure and composition of woody plant communities in savannas?

\section{Research method and design}

\section{Study sites}

Three long-term herbivore exclosures ( $>40$ years old) exist in the KNP. These include the Nhlangwini exclosure near Pretoriuskop, the Makhohlola exclosure near Crocodile Bridge and the N'waxitshumbe exclosure on the northern plains (Table 1). At each exclosure two treatments were sampled, one inside the exclosure and one outside the exclosure at close proximity.

The 220.0 ha Nhlangwini exclosure was established in 1973 and occurs in the south-western portion of the KNP near Pretoriuskop rest camp. This is the wettest part of KNP with mean average precipitation close to $750 \mathrm{~mm}$. The exclosure is situated within the broad-leaved bushveld vegetation

TABLE 1: Site names, locations and descriptions of the exclosures in the Kruger National Park where sampling took place.

\begin{tabular}{|c|c|c|c|c|c|}
\hline Site & Location & Rainfall (mm) & Geology & GPS coordinates East & GPS coordinates South \\
\hline Nhlangwini exclosure & Pretoriuskop & 750 & Granites & $31.292633^{\circ}$ & $-25.19907^{\circ}$ \\
\hline Makhohlola exclosure & Crocodile Bridge & 600 & Basalts & $31.913737^{\circ}$ & $-25.262083^{\circ}$ \\
\hline N'waxitshumbe exclosure & Northern Plains & 400 & Basalts & $31.25825^{\circ}$ & $-22.77818^{\circ}$ \\
\hline
\end{tabular}


type that occurs on sandy soils derived from granitic rocks, common species include Terminalia sericea and $S$. birrea (Venter, Scholes \& Eckhardt 2003). Mean fire return interval is similar inside and out, with fire occurring on average every 3.6 years inside (Asner et al. 2009) and less than every 4 years outside (Smit et al. 2012). The Makhohlola exclosure is a 2.4 ha exclosure constructed in the early 1970s. It is located in the south-eastern corner of the KNP, just north of Crocodile Bridge. It occurs in the $S$. birrea-A. nigrescens savanna type (Venter et al. 2003). The site occurs on soils derived from rocks of basaltic origin with mean annual rainfall of c. $600 \mathrm{~mm}$. The mean fire return interval in the Makhohlola exclosure (4.5 years) was slightly longer than outside (3.2 years), until 2004 when a new fire experiment was set up (see Levick et al. 2009). Since 2004, half of the exclosure has been protected from fire, whilst the other half is burnt in conjunction with the surrounding landscape (Levick et al. 2009). From 2004 to the time of measurements in March 2011, the burn treatment and surrounding areas were burnt twice: in 2006 and 2010. The N'waxitshumbe exclosure is situated in the arid north-eastern section of the KNP and was established in 1967. The original N'waxitshumbe exclosure was 230.0 ha, with an additional 72.0 ha added in 1986 (Asner et al. 2009). Mean annual precipitation is close to $400 \mathrm{~mm}$ and the soils here are derived from rocks of basaltic origin. The vegetation type is classified as Colophospermum mopane shrubveld growing in broad-leaved bushveld (Venter et al. 2003). The mean fire return interval for the N'waxitshumbe exclosure is approximately 4 years (Asner et al. 2009), whilst Smit et al. (2012) showed that the area surrounding the N'waxitshumbe exclosure has a mean fire return interval of less than 4 years.

The faunal assemblage in the park includes all the major mammal species typical of the region. Common browser species include kudu Tragelaphus strepsiceros (Pallas 1766), giraffe Giraffa camelopardalis (Linnaeus 1758), black rhinoceros Diceros bicornis (Linnaeus 1758), steenbok Raphicerus campestris (Thunberg 1811), grey duiker Sylvicapra grimmia (Linnaeus 1758) and bushbuck Tragelaphus scriptus (Pallas 1766). Common mixed-feeders include impala Aepyceros melampus (Lichtenstein 1812) and the African elephant Loxodonta africana (Linnaeus 1758).

\section{Community composition}

The distribution, abundance and density of the species growing both inside and outside of each of the exclosures was determined by walking four $100 \mathrm{~m}$ long by $4 \mathrm{~m}$ wide transects for each treatment at each site $\left(1600 \mathrm{~m}^{2}\right)$ in March 2011 . The four transects in each treatment were taken parallel to each other and $50 \mathrm{~m}$ apart. Inside and outside pairs were situated in as close a proximity as fences and firebreaks permitted. Care was also taken to ensure that the paired transects were on similar positions along catenal gradients. At Nhlangwini, the paired transects were taken perpendicular to the northern fence of the exclosure and parallel to the drainage in the area, outside transects were taken to the north-west of the exclosure. At Makhohlola, the paired transects were taken perpendicular to the western fence and perpendicular to the drainage at the site, outside transects were taken to the north of the exclosure. Owing to the limited size of the Makhohlola exclosure $(100 \mathrm{~m} \times 240 \mathrm{~m})$ two of the four transects were taken in the no-burn part of the fire experiment (since 2004) and two were taken in the part that burns in conjunction with the surrounding landscape. At N'waxitshumbe, the paired transects were taken perpendicular to the southern fence in the south-western portion of the exclosure and parallel to the drainage in that area.

Species identity was recorded for each woody plant encountered in each transect using a personal digital assistant (PDA) with CyberTracker software. The abundance data were used to create an inside abundance index, whereby the proportion of a species found in the inside compared to the outside treatment was calculated. This index was calculated by dividing the number of individuals of each species found inside by the total number of individuals found both inside and outside. Thus a value of 1 indicates the species was only found inside, whilst a value of 0 indicates the species was only found outside. The inside abundance index was then plotted against a suite of leaf traits to test whether species growing on the inside had high values of these traits. This index can be used as a proxy to determine which plant species are preferentially selected for or 'favoured' by browsers relative to their abundance.

\section{Trait sampling}

The dominant woody plant species making up $80 \%$ - $90 \%$ of the woody biomass inside and outside the three exclosures in the KNP were determined (Table 2). Fourteen different plant traits relating to the leaves and stems were sampled for each species. All trait data (except BSI) were measured and

TABLE 2: Dominant woody species accounting for $>80 \%$ of standing biomass for inside and outside treatments at the three Kruger National Park exclosures.

\begin{tabular}{lll}
\hline Site & Treatment & Species \\
\hline Makhohlola & In & Acacia gerrardii \\
Makhohlola & In & Acacia nigrescens \\
Makhohlola & In & Dalbergia melanoxylon \\
Makhohlola & In & Lannea schweinfurthii \\
Makhohlola & Out & Albizia harveyi \\
Makhohlola & Out & Gymnosporia senegalensis \\
Makhohlola & Out & Acacia gerrardii \\
Makhohlola & Out & Acacia nigrescens \\
Nhlangwini & In & Dalbergia melanoxylon \\
Nhlangwini & In & Euclea divinorum \\
Nhlangwini & In & Grewia monticola \\
Nhlangwini & In & Strychnos madagascariensis \\
Nhlangwini & Out & Antidesma venosum \\
Nhlangwini & Out & Dichrostachys cinerea subsp. africana \\
Nhlangwini & Out & Sclerocarya birrea \\
Nhlangwini & Out & Terminalia sericea \\
N'waxitshumbe & In & Dalbergia melanoxylon \\
N'waxitshumbe & In & Grewia monticola \\
N'waxitshumbe & In & Ozoroa paniculosa \\
N'waxitshumbe & In & Pterocarpus rotundifolius \\
N'waxitshumbe & In & Sclerocarya birrea \\
N'waxitshumbe & Out & Colophospermum mopane \\
N'waxitshumbe & Out & Combretum imberbe \\
N'waxitshumbe & Out & Philenoptera violacea \\
\hline
\end{tabular}

In, inside treatment; Out, outside treatment. 
recorded according to the methods explained in Cornelissen et al. (2003). For each species, leaf material was collected from five individuals and analysed for N, P and carbon $(\mathrm{C})$ content using a Leco TruSpec CN Analyser (LECO Corporation, St. Joseph, MI). SLA and average leaf area were measured using four healthy and complete sun-exposed leaves from five individuals (20 leaves per species). The BSI of a species is the total dry weight of the leaves removed from two human bites taken from five individuals (total of ten bites). An attempt was made to remove the maximum amount of leaf material with each bite. The BSI for all species was measured by the same person in order to control for potential differences between individual recorders. Total condensed tannins were calculated according to the methods described by Hattas and Julkunen-Tiitto (2012), whilst total polyphenols (TP) were calculated according to the methods described by Hattas et al. (2005). Cell wall constituents, that is, NDF and ADF, were determined in an Ankom fibre analyser (Ankom Technology Corp., Fairport, NY), whereas ADL was determined in accordance with the acid detergent lignin in beakers method. Ash was determined by incinerating the filter bag containing plant residue in a muffle furnace at $525^{\circ} \mathrm{C}$ for $3 \mathrm{~h}$. All cell wall constituents were determined consecutively as outlined in the Ankom Technology procedures (Ankom Technology 2010).

\section{Soil sampling}

Five replicate soil samples were collected both inside and outside of each exclosure at three depths $(0 \mathrm{~cm}-10 \mathrm{~cm}, 10 \mathrm{~cm}$ $-20 \mathrm{~cm}$ and $40 \mathrm{~cm}-50 \mathrm{~cm}$ ) using a soil auger. Care was taken to sample away from the canopies of trees. Soil bulk density measurements were taken at these same depths. The methods used for soil sampling and analyses are described in detail by Wigley et al. (2013).

\section{Statistical analyses}

All analyses were performed using R (R Project 2012). Chisquare tests were used to test for differences in tree densities between treatments. Non-parametric Wilcoxon tests were used to test for differences in trait measurements as the low replication resulting from the low species diversity at each site precluded the use of statistical tests founded on the normal distribution. Analyses of variances were used to test for differences in soil nutrients between treatments using pooled data from all three depths, as the conditions for homoscedasticity were not violated (fligner test: $p>0.05$; Conover, Johnson \& Johnson 1981). Principle components analyses (PCA) were used to explore the relationships between treatments, sites and measured plant traits. The function 'PCAsignificance' available in the BiodiversityR package (Kindt \& Coe 2005) in R was used to test for significant PCA axes using the broken-stick distribution.

\section{Results}

\section{Community composition data}

At the Nhlangwini exclosure, there were a number of differences between the two communities. The four most common species for both treatments were T. sericea, Dichrostachys cinerea, S. birrea and Acacia gerrardii. However, T. sericea was found to be much more abundant (nearly $80 \%$ of all trees) inside compared to outside (c. $35 \%$ ) of the exclosure (Figure 1). Dichrostachys cinerea showed the opposite pattern, with a higher relative abundance outside (30\%) compared to inside $(15 \%)$ the exclosure (Figure 1). Sclerocarya birrea and A. gerrardii showed similar abundances between treatments (Figure 1). Both treatments had a few unique species, with Strychnos madagascariensis, Catunaregam spinosa and Searsia leptodictya only found inside, whilst Antidesma venosum, Combretum hereroense, Albizia harveyi, Philenoptera violacea and Piliostigma thonningii were only found outside. Species diversity was found to be higher on the outside of the exclosure, with a total of 16 species compared to 12 species inside.

There were distinct differences in woody communities growing inside and outside of the Makhohlola exclosure (Figure 1). Acacia nigrescens was found to be more abundant inside the exclosure (32\%) but was still relatively abundant outside (22\%). Flueggea virosa was common inside (15\%) but rare outside (4\%). Gymnosporia senegalensis was found to have a much higher abundance outside (33\%) compared to inside (12\%). Lannea schweinfurthii and S. birrea had lower abundances outside (7\% and 1\%, respectively) compared to inside (12\% and 7\%, respectively). Dichrostachys cinerea and $A$. harveyi were relatively common outside (13\% and $9 \%$, respectively) but rare inside (3\% for both). Dalbergia melanoxylon, Ehretia rigida and Euclea undulata were only found inside the exclosure, making species diversity higher on the inside (13 species) than outside (10 species).

There were also distinct differences in the woody communities growing inside and outside of the N'waxitshumbe exclosure. At this site, C. mopane was found to be the most common species both inside $(43 \%)$ and outside $(40 \%$, Figure 1$)$. The second most common species inside the exclosure (37\%), D. melanoxylon, was not found outside of the exclosure. Combretum imberbe and $P$. violacea were more common outside ( $14 \%$ for both) compared to inside (7\% and $1 \%$, respectively). Sclerocarya birrea and G. senegalensis were relatively rare both inside and outside of the exclosures. Dalbergia melanoxylon, Grewia monticola and Ozoroa obovata were unique to inside, whilst $D$. cinerea, $A$. harveyi and $A$. nigrescens were only found outside of the exclosure. Thus species diversity was the same inside and outside of the exclosure, but species composition differed.

\section{Population structure}

Total woody plant densities were significantly higher for the inside treatments at all three sites (Figure 2). These large differences were determined by the most common species growing at each site. The size class distributions for the two most common species growing at the Nhlangwini exclosure (T. sericea and $D$. cinerea) show very different patterns for each treatment. The size class distribution of $T$. sericea inside the exclosure shows an inverse J-shaped curve, with many plants in the smaller size classes less than $3 \mathrm{~m}$ and fewer plants in the large size classes. The size class distribution for outside the exclosure shows much lower numbers of plants in the smaller size classes and fewer plants in the very large 

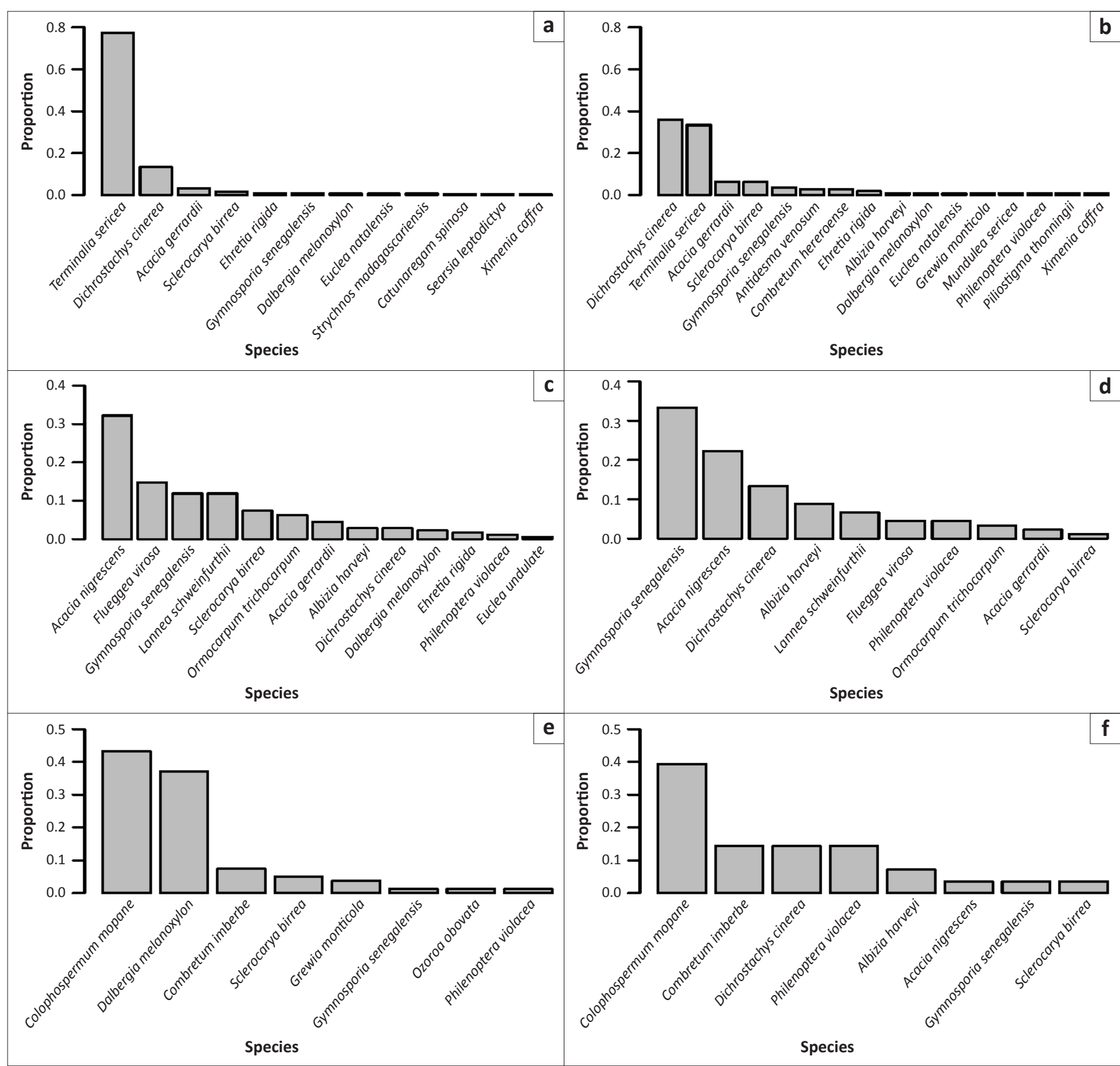

FIGURE 1: The relative abundance of the species found inside and outside the three exclosures namely Nhlangwini (a) inside and (b) outside, Makhohlola (c) inside and (d) outside and N'waxitshumbe (e) inside and (f) outside, in the Kruger National Park.

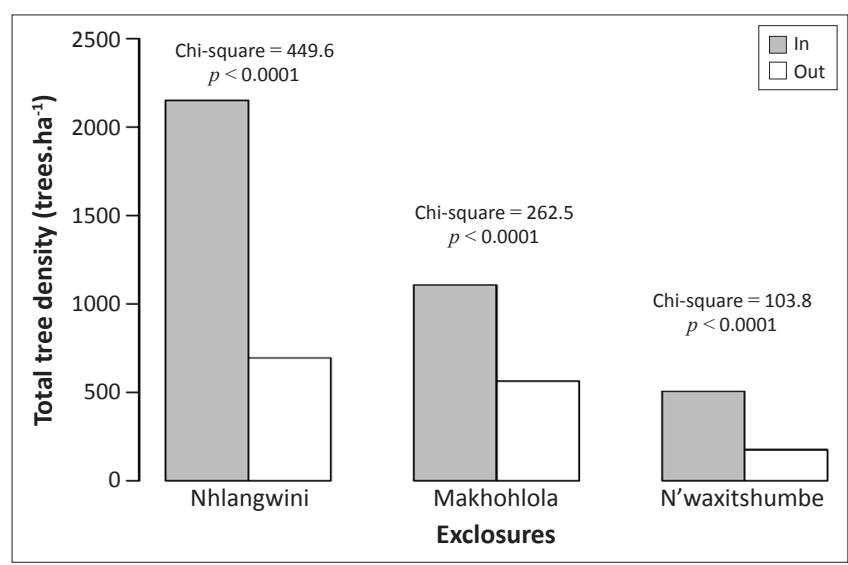

FIGURE 2: Total tree densities for all woody plants greater than $0.5 \mathrm{~m}$ in height inside and outside the three long-term herbivore exclosures in the Kruger National Park. size classes (Figure 3). A different pattern was evident for $D$. cinerea, with most plants falling into size classes between $2 \mathrm{~m}$ and $4 \mathrm{~m}$ inside the exclosure, whilst plants on the outside were more evenly distributed in a greater range of size classes (Figure 3).

At Makhohlola, major differences were evident between treatments for each of the four most common species (Figure 4). The size class distributions of L. schweinfurthii and $A$. nigrescens showed an approximately inverse J-shaped curve for the populations growing inside the exclosures but not for the outside populations. The inside populations of these two species both had a much higher number of individuals in the smaller $(<2 \mathrm{~m})$ size classes than the outside populations (Figure 4). The outside population of G. senegalensis was more uniform in height $(1 \mathrm{~m}-2 \mathrm{~m})$ than 

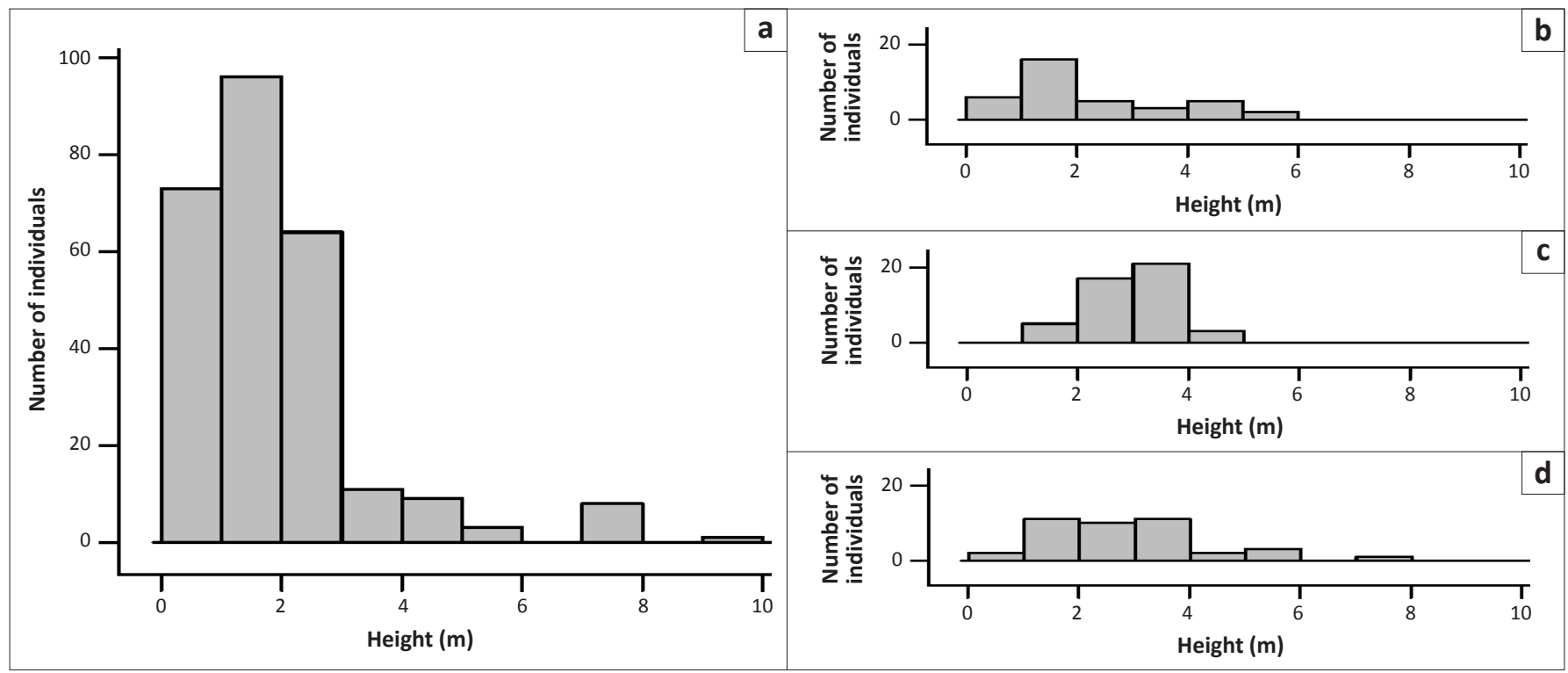

FIGURE 3: Size class distributions of Terminalia sericea populations growing (a) inside and (b) outside and Dichrostachys cinerea populations growing (c) inside and (d) outside of the Nhlangwini exclosure in the Kruger National Park.
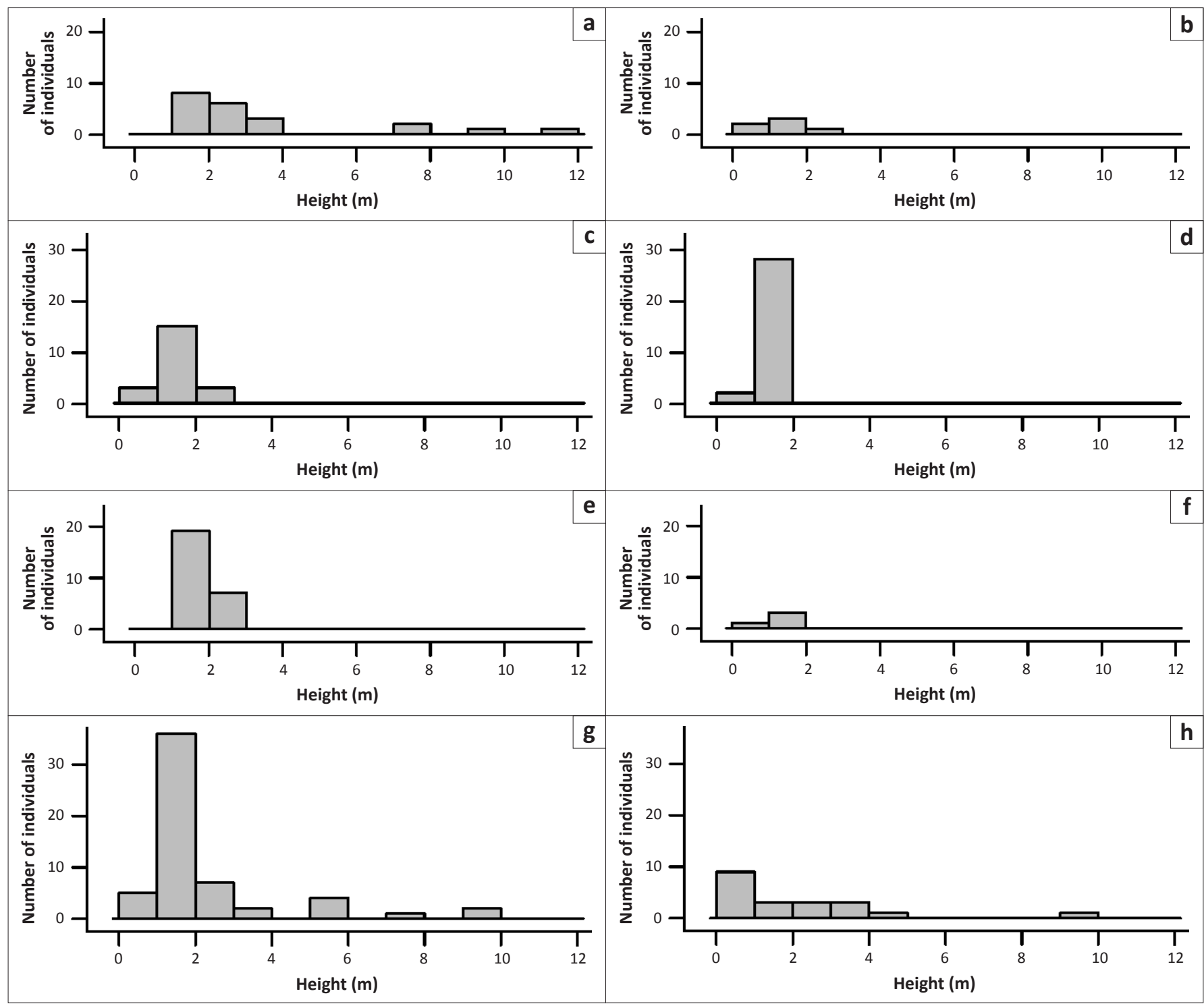

FIGURE 4: Size class distributions of Lannea schweinfurthii populations growing (a) inside and (b) outside, Gymnosporia senegalensis populations growing (c) inside and (d) outside, Flueggea virosa populations growing (e) inside and ( $\mathrm{f}$ ) outside and Acacia nigrescens populations growing (g) inside and (h) outside of the Makhohlola exclosure in the Kruger National Park. 
the inside population $(0 \mathrm{~m}-3 \mathrm{~m})$. There were many more and taller F. virosa plants growing on the inside of the exclosure compared to the outside (Figure 4).

At N'waxitshumbe, the two most common species $C$. mopane and $C$. imberbe had similar size class distributions in each treatment (Figure 5). However, there were higher densities in each size class for the inside treatment for $C$. mopane, whilst $C$. imberbe had similar numbers in each size class for both populations. The most striking difference was found for D. melanoxylon, where a population spanning the full range of size classes was found inside the exclosure, whilst not one individual was found outside of the exclosure in the sampling area (Figure 5).

\section{Leaf traits of unique inside species versus common outside species}

There were no significant differences $(p>0.05$; Wilcoxon test) in leaf nutrient concentrations $-\mathrm{N}, \mathrm{C}, \mathrm{C}: \mathrm{N}, \mathrm{P}$, Calcium (Ca), Magnesium (Mg), Sodium (Na) and Potassium (K) between each of the inside and outside treatments (Table 3 ).
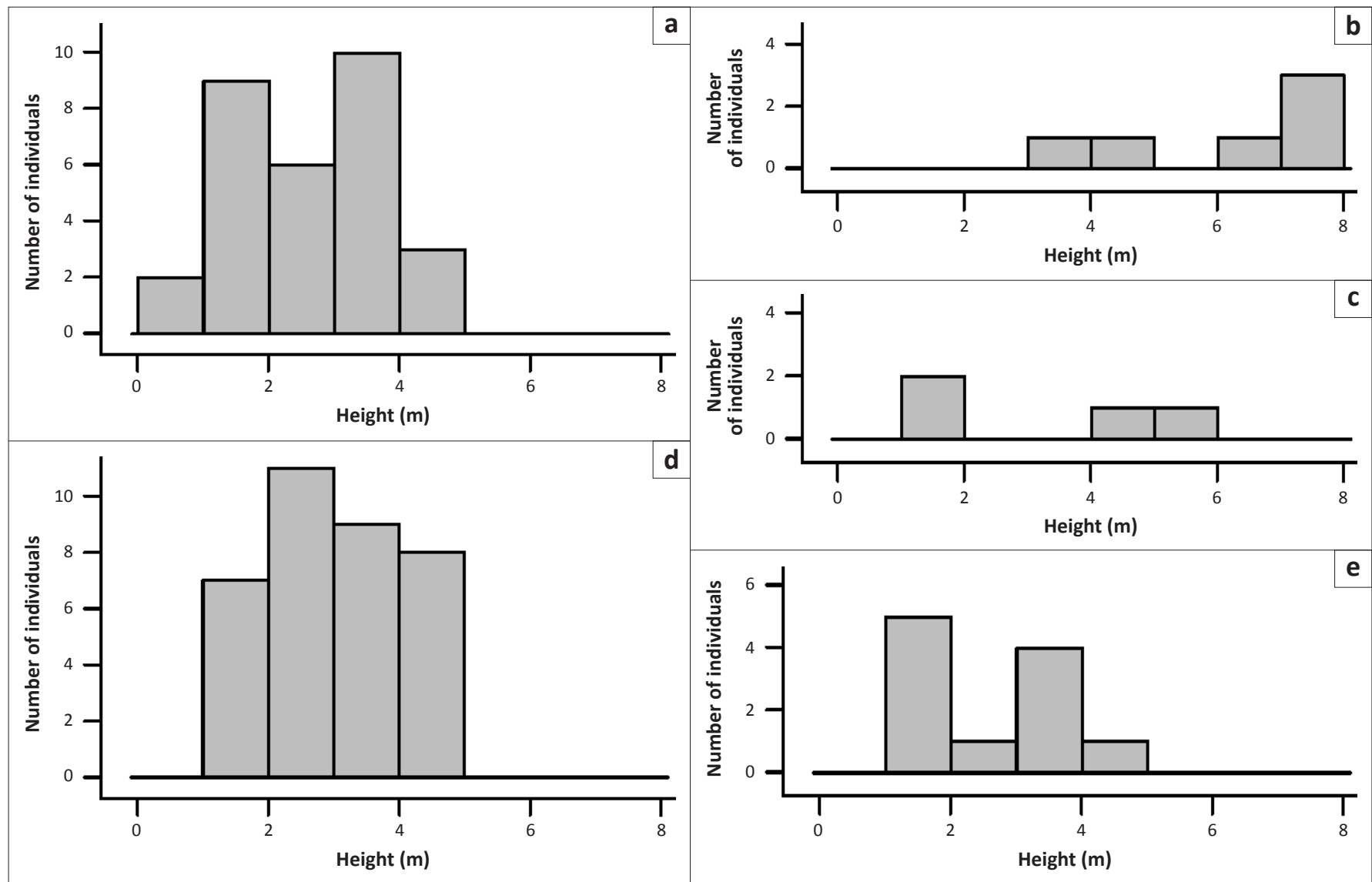

FIGURE 5: Size class distributions of Dalbergia melanoxylon populations growing (a) inside, Combretum imberbe populations growing (b) inside and (c) outside and Colophospermum mopane populations growing (d) inside and (e) outside of the N'waxitshumbe exclosure. No Dalbergia melanoxylon plants were found growing on the outside of the exclosure in the Kruger National Park.

TABLE 3: Mean ( \pm s.e.) values of the measured leaf traits for the inside and outside treatments of three exclosures in the Kruger National Park.

\begin{tabular}{|c|c|c|c|c|c|c|}
\hline \multirow[t]{2}{*}{ Trait } & \multicolumn{2}{|c|}{ Makhohlola } & \multicolumn{2}{|c|}{ N'waxitshumbe } & \multicolumn{2}{|c|}{ Nhlangwini } \\
\hline & In & Out & In & Out & In & Out \\
\hline Leaf N (\%) & $2.48 \pm 0.25$ & $2.16 \pm 0.16$ & $2.15 \pm 0.43$ & $1.83 \pm 0.26$ & $2.35 \pm 0.53$ & $1.50 \pm 0.330$ \\
\hline Leaf C (\%) & $39.40 \pm 2.00$ & $36.70 \pm 0.88$ & $46.30 \pm 1.33$ & $44.90 \pm 1.76$ & $45.50 \pm 0.40$ & $46.10 \pm 2.390$ \\
\hline Leaf C:N & $16.10 \pm 1.03$ & $16.90 \pm 1.50$ & $25.60 \pm 5.27$ & $25.60 \pm 4.09$ & $21.40 \pm 4.65$ & $32.20 \pm 5.280$ \\
\hline Leaf P (\%) & $0.13 \pm 0.01$ & $0.12 \pm 0.02$ & $0.21 \pm 0.04$ & $0.23 \pm 0.08$ & $0.11 \pm 0.02$ & $0.09 \pm 0.001$ \\
\hline $\operatorname{SLA}\left(\mathrm{cm}^{2} \mathrm{~g}^{-1}\right)$ & $80.20 \pm 9.08$ & $57.30 \pm 19.50$ & $82.60 \pm 10.30$ & $120.00 \pm 69.10$ & $93.60 \pm 9.16$ & $81.40 \pm 7.450$ \\
\hline Leaf size $\left(\mathrm{cm}^{2}\right)$ & $28.00 \pm 14.70$ & $12.70 \pm 3.57$ & $46.90 \pm 16.10$ & $41.30 \pm 25.30$ & $15.70 \pm 5.73$ & $38.00 \pm 14.800$ \\
\hline BSI & $11.00 \pm 5.73$ & $8.06 \pm 3.56$ & $19.80 \pm 4.52$ & $18.80 \pm 2.45$ & $4.12 \pm 0.82$ & $9.50 \pm 1.600$ \\
\hline $\mathrm{TS}\left(\mathrm{N} \mathrm{mm}^{-1}\right)$ & $1.35 \pm 0.43$ & $2.44 \pm 0.93$ & $0.71 \pm 0.09$ & $1.14 \pm 0.20$ & $0.91 \pm 0.14$ & $0.75 \pm 0.270$ \\
\hline TP $(\%)$ & $0.95 \pm 0.08$ & $1.24 \pm 0.22$ & $2.62 \pm 0.41$ & $3.21 \pm 1.20$ & $2.23 \pm 0.46$ & $4.68 \pm 1.470$ \\
\hline СТ (\%) & $5.11 \pm 1.30$ & $3.99 \pm 0.79$ & $2.68 \pm 0.73$ & $3.56 \pm 1.50$ & $4.03 \pm 2.61$ & $4.41 \pm 1.710$ \\
\hline NDF $(\%)$ & $60.80 \pm 2.65$ & $58.00 \pm 4.53$ & $49.70 \pm 3.62$ & $42.90 \pm 6.44$ & $52.30 \pm 4.34$ & $57.30 \pm 2.570$ \\
\hline ADF $(\%)$ & $36.20 \pm 6.33$ & $37.50 \pm 4.59$ & $33.90 \pm 4.07$ & $28.30 \pm 6.76$ & $32.90 \pm 2.02$ & $37.20 \pm 4.470$ \\
\hline ADL $(\%)$ & $15.40 \pm 3.67$ & $18.90 \pm 3.32$ & $4.45 \pm 1.50$ & $8.89 \pm 3.55$ & $5.61 \pm 1.46$ & $7.43 \pm 3.190$ \\
\hline
\end{tabular}

$\mathrm{N}$, nitrogen; C, carbon; C:N, carbon-nitrogen ratio; P, phosphorus; SLA, specific leaf area; BSI, bite size index; TS, leaf tensile strength; TP, total polyphenols; CT, condensed tannins; NDF, neutral detergent fibre; $A D F$, acid detergent fibre; ADL, acid detergent lignin; In, inside treatment; Out, outside treatment. 
There were, however, some consistent trends; the lack of statistically significant differences was likely a result of the small sample sizes resulting from low woody species diversity at the sites. Mean leaf N (\%) was noticeably higher for the inside treatment at all three sites (Table 3). The higher $\mathrm{N}$ and similar $\mathrm{C}$ concentrations inside of the Nhlangwini exclosure resulted in a lower mean $\mathrm{C}: \mathrm{N}$ ratio, whilst the other two sites had similar C:N ratios (Table 3). Leaf P (\%) was similar between treatments at all three sites (Table 3).

There were no significant differences ( $p>0.05$; Wilcoxon test) in SLA, leaf size, BSI and tensile strength between treatments. Mean SLA was consistently higher for species restricted to the inside treatments (Table 3). Average leaf area, which was highly correlated to BSI, were both higher inside the exclosures at the two nutrient rich sites on basalts (Makhohlola and $\mathrm{N}^{\prime}$ waxitshumbe), whilst the opposite pattern was true for the Nhlangwini site which is situated on nutrient poor granite derived soils (Table 3). Mean leaf tensile strength was higher outside exclosures at the two basalt sites, but no difference was evident between treatments at the granite site (Table 3).

The pooled data showing the inside abundance index of each species plotted against leaf traits and BSI showed a weak positive relationship between the inside abundance index and leaf $\mathrm{N}$ and $\mathrm{P}$ (Figures $6 \mathrm{a}$ and $6 \mathrm{~b}$ ). Almost no relationship was evident between the inside abundance index and SLA and BSI (Figures $6 \mathrm{c}$ and $6 \mathrm{~d} ; p>0.05$ for all correlations).

\section{Chemical defence}

No significant differences ( $p>0.05$; Wilcoxon test) in total phenolics, condensed tannins and fibre were evident between treatments. However, an interesting pattern emerged; mean leaf phenolic concentrations were consistently lower for species restricted to the inside treatments compared to those in the outside treatment, with the biggest difference evident at the Nhlangwini site (Table 3). Mean condensed tannin concentrations showed no consistent patterns between treatments and sites (Table 3). The three types of fibre analyses showed different patterns. NDF, which includes hemicellulose, cellulose and lignin, was slightly lower for the outside treatments at Makhohlola and N'waxitshumbe, whilst the opposite pattern was found at Nhlangwini (Table 3). ADF, which includes cellulose and lignin, showed no consistent patterns (Table 3). ADL, which only includes lignin, was consistently lower for the inside treatments at all three sites (Table 3).

\section{Soil nutrients}

Although the pooled data for all depths of soil $\mathrm{N}$ and $\mathrm{P}$ showed a pattern of higher values for the three inside treatments, the only statistically significant differences were evident at N'waxitshumbe ( $p<0.05$; Figures 7a and 7c). Soil $\mathrm{C}$ and $\mathrm{K}$ also showed a pattern of being consistently higher for the inside treatments at Makhohlola and N'waxitshumbe, with no differences evident at Nhlangwini (Figures $7 b-7 d$ ). Similar patterns were evident for N, C and P when total

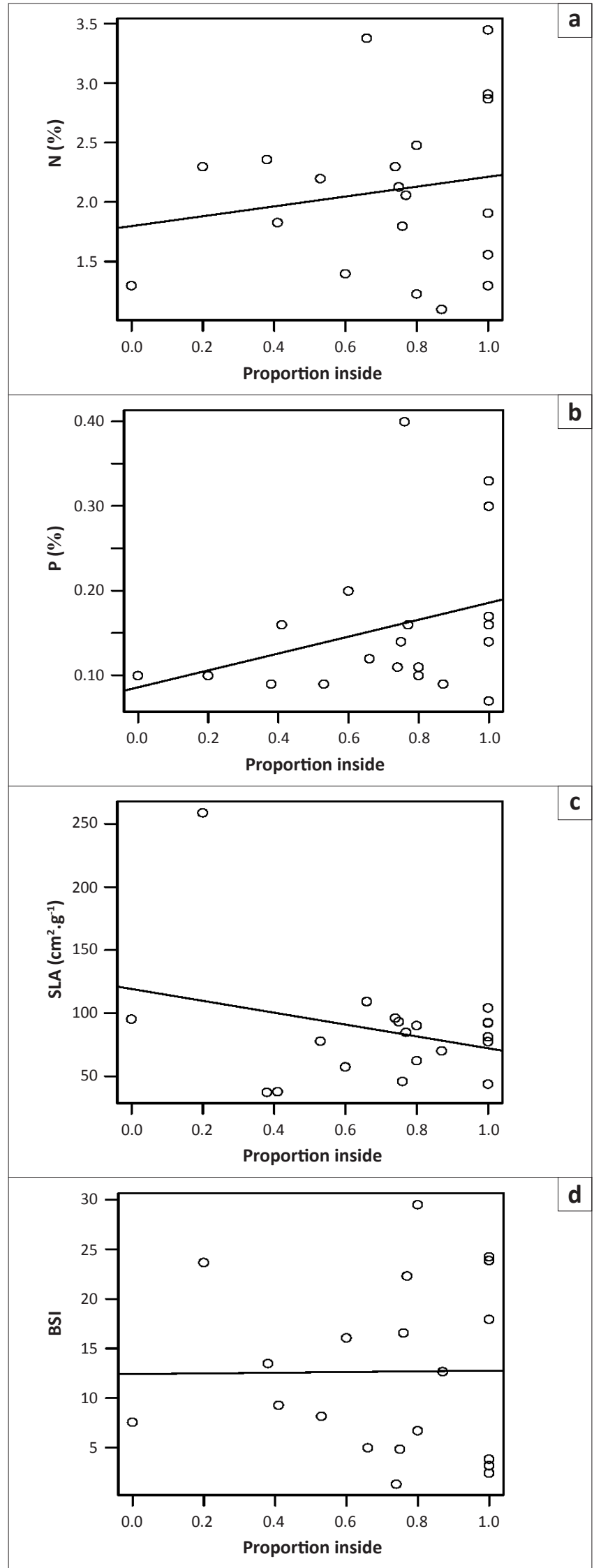

$\mathrm{N}$, nitrogen; P, phosphorus; SLA, specific leaf area; BSI, bite size index.

FIGURE 6: Data for, (a) leaf nitrogen, (b) leaf phosphorus, (c) specific leaf area and (d) bite size index plotted against the proportion of species found on the inside compared to the outside of three exclosures in the Kruger National Park. A value of 1 indicates that the species was only found inside, whilst a value of 0 indicates the species was only found outside the exclosures. 


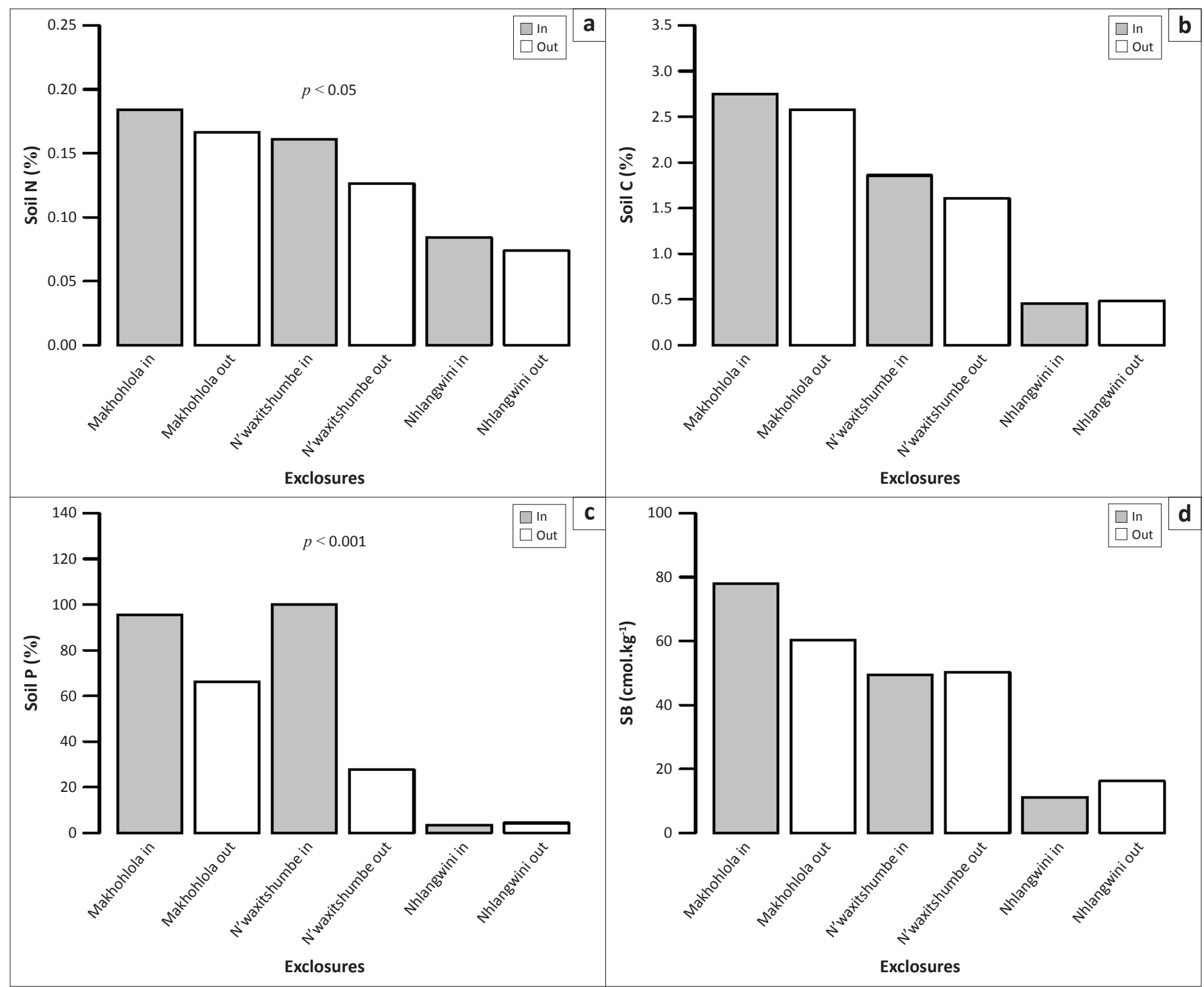

$\mathrm{N}$, nitrogen; C, carbon; P, phosphorus; SB, Sum of Bases; in, inside treatment; out, outside treatment. $N=15$ for each treatment.

FIGURE 7: Mean ( \pm s.e.) for, (a) soil nitrogen, (b) carbon, (c) phosphorus and (d) potassium concentrations inside and outside of three exclosures in the Kruger National Park. Plotted means are calculated from five replicates taken at three depths.

nutrient stocks were calculated using soil bulk density data (data not shown).

\section{Multivariate analyses}

The PCA performed on the data using 13 traits relating to the leaves and stem (Figure 8) showed that the first two principal components together explained $44.0 \%$ of the total variation amongst species. The most important traits separating species along the first PCA axis were NDF, ADL and TP. The most important traits separating species along the second PCA axis were leaf $\mathrm{N}$, leaf $\mathrm{C}: \mathrm{N}$ and stem density (Figure 8). The PCA showed that the species from the inside tended to more variable along PCA axis 2 (higher leaf $\mathrm{N}$ and stem density), whilst the species from the outside tend to be more variable along PCA axis 1 (higher fibre and TP values). The variance explained by the first PCA axis was found to be insignificant, as the percentage of explained variance (24.3\%) was not larger than the corresponding percentage of variance of the broken- stick distribution $(24.5 \%)$, whilst the second PCA axis was significant as the percentage of explained variance (20.3\%) was larger than the corresponding percentage of variance of the broken-stick (16.8\%) distribution (Kindt \& Coe 2005).

\section{Discussion}

Clear differences were found in both the species composition and population structure of the woody plant communities growing inside and outside of three herbivore exclosures in the KNP. Although the three exclosures were situated in very different vegetation types, some similarities exist in species' responses to low herbivory. Some species were frequently encountered both inside and outside of the exclosures (e.g. T. sericea and D. cinerea at Nhlangwini, A. nigrescens and G. senegalensis at Makhohlola, C. mopane at N'waxitshumbe). Smaller size classes tended to be better represented inside, and larger size classes outside, for species which were found in large numbers both inside and outside of the exclosures. 


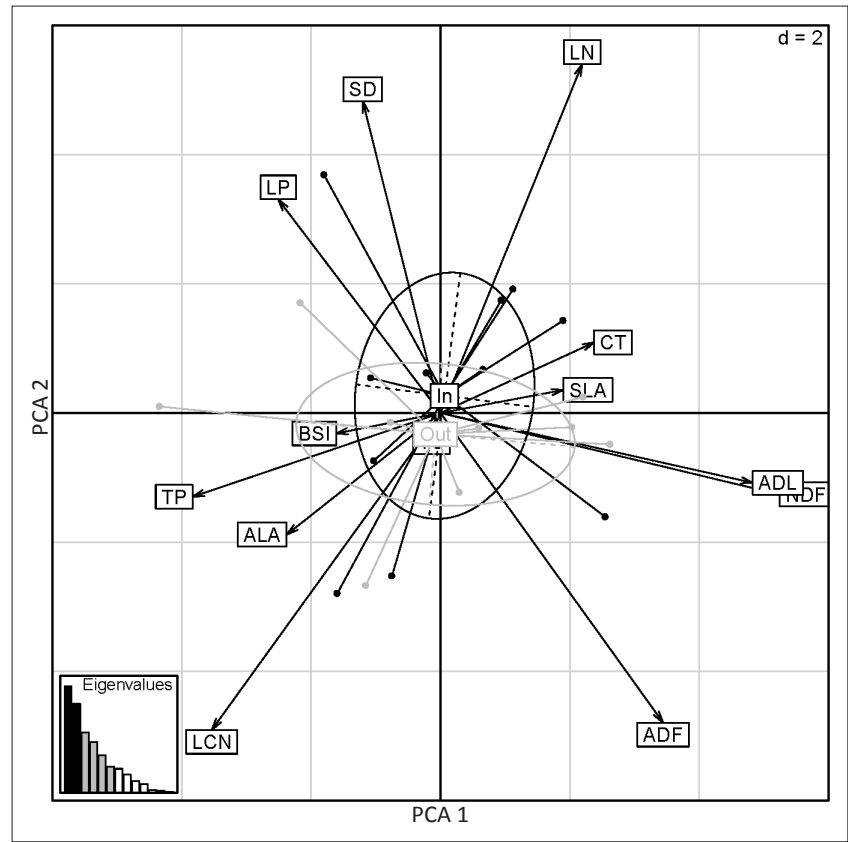

$P C A$, principal components analysis; $L P$, leaf phosphrus; $S D$, stem density; $L N$, leaf nitrogen; $C T$, condensed tannins; SLA, specific leaf area; ADL, acid detergent lignin; NDF, neutral detergen fibre; ADF, acid detergent fibre; LCN, leaf carbon to nitrogen ratios; ALA, average leaf area; TP, total phenolics; BSI, bite size index.

Neutral detergent fibre, acid detergent lignin and total phenolics were most influential along PCA axis 1 ( $24 \%$ of total variation), whilst leaf nitrogen, leaf carbon-nitrogen ratio and stem density were most influential along PCA axis 2 ( $20 \%$ of total variation). The locations of each specie on the first two PCs are shown as well as the groupings by treatment (inside versus outside).

FIGURE 8: Principal components analysis of trait measurements from 20 species sampled inside and outside of three exclosures in the Kruger National Park.

There were some exceptions though; G. senegalensis for instance, had similar population structures both inside and out. This could be because this species is not a preferred browsing species as a result of the high condensed tannin and ADL concentrations in the leaves (see Shrader et al. 2011). We argue that savanna woody species are either well adapted to browsing (such as D. cinerea), well defended (such as G. senegalensis) or both (such as A. nigrescens). For example, Fornara and Du Toit (2007) showed that heavily browsed $A$. nigrescens trees develop tolerance traits, such as high regrowth rates and extensive branching, as well as resistance traits, such as close thorn spacing, suggesting that it is both well adapted and well defended. In fact, a metaanalysis by Carmona, Lajeunesse and Johnson (2011) has shown that secondary metabolites are less important in plant defence when compared to other defensive plant traits such as physical resistance, gross morphology and growth rates.

Some species were found more frequently outside of the exclosures, such as D. cinerea, which was found in higher numbers outside of the exclosure at Nhlangwini, and A. harveyi at all exclosures. These species are most likely stimulated by disturbance, for example $D$. cinerea shrubs rootsucker, and expand significantly when stimulated by fire and browsing (Wakeling \& Bond 2007). More frequently, species were only found inside the exclosures (e.g. D. melanoxylon, G. monticola and O. obovata at N'waxitshumbe). Dalbergia melanoxylon had the highest leaf $\mathrm{N}$ of all the species in this study and we assume that the species found only on the inside of the exclosures are mostly very palatable and targeted by browser species outside of the exclosures. Dalbergia melanoxylon was found outside of the $\mathrm{N}^{\prime}$ waxitshumbe exclosure in a previous study, but in lower lying areas than at our study area (Levick \& Rogers 2008). It is uncertain whether D. melanoxylon has since disappeared outside the exclosure or whether this species may be preferentially targeted by browsers at specific positions along the catena.

Why do species become locally extinct outside of exclosures? Impala and kudu are highly selective when foraging in nutrient-poor broadleaf savannas (Cooper \& Owen-Smith 1985; Owen-Smith \& Cooper 1987). This selectivity is attributed to differences amongst species in the level of defensive chemical compounds. Alternatively, these species may also be predisposed to pollarding, uprooting and ringbarking and coppice poorly in response to elephant damage (O'Connor, Goodman \& Clegg 2007). A number of studies have documented the local extinction of plant species resulting from elephant impact (e.g. Boundja \& Midgley 2010; O'Connor et al. 2007 and references therein; Penzhorn, Robbertse \& Olivier 1974). Several studies have shown that other herbivores can lead to the local extirpation of plant species. Bond and Loffel (2001) found that Acacia davyi was no longer found in areas accessible to giraffe in Ithala Game Reserve.

Total tree densities were significantly higher for the inside treatments at all three sites, usually with more individuals falling into the smaller size classes inside of the exclosures. These findings are in strong agreement with previous studies from the same study sites. Trollope et al. (1998), Levick and Rogers (2008) and Asner et al. (2009) reported higher tree densities and different population structures between treatments. Moncrieff et al. (2011) reported different tree allometries between trees growing inside and outside of the same herbivore exclosures in the KNP, with heavily browsed trees shorter for a given stem diameter. Our results are therefore in agreement with previous studies and provide strong evidence that herbivory has a major impact on savanna woody plant diversity, species population structure and overall woody plant densities.

The next step was to determine if there were differences between treatments for some of the key plant functional traits of each woody community. There was a trend in leaf $\mathrm{N}$ concentration, with higher mean $\mathrm{N}$ for the species unique to the inside treatments compared to the species found growing outside. No obvious patterns or trends were evident for leaf C:N or P. Leaf structural traits, SLA, average leaf size and BSI, which are all correlated, showed similar trends with higher values inside the exclosures at the two fertile sites and lower values inside compared to outside at the infertile site. The opposite pattern was evident for tensile strength where the leaves were generally tougher on the outside at the two fertile sites with no difference at the infertile site. Apart from leaf N, total phenolic content and lignin content were the only traits that showed consistent patterns between treatments with higher values for species outside of the exclosures. Increases 
of carbon-based structural metabolites with decreases in leaf $\mathrm{N}$ have been shown with high browsing intensity in previous work (Bryant et al. 1991; Wessels, Van der Waal \& De Boer 2007). An alternative theory for increases in lignin and leaf $\mathrm{N}$ inside the exclosures may be that herbivores preferentially select species with higher leaf $\mathrm{N}$ and that species with lower total phenolic and lignin content are also targeted by herbivores.

In general, the removal of browsers led to higher soil nutrients, the response was the greatest at the two basalt sites. At $\mathrm{N}^{\prime}$ waxitshumbe differences in soil $\mathrm{N}$ and $\mathrm{P}$ were higher with browsers absent, whilst soil $\mathrm{C}$ and $\mathrm{K}$ were also higher inside of the exclosures. The same pattern was evident at Makhohlola, whilst the nutrient-poor site (Nhlangwini) showed almost no differences between treatments for all measured soil nutrients. Although herbivores have been found to increase soil nutrients (e.g. Augustine \& McNaughton 2006; Frank 2008), Ritchie, Tilman and Knops (1998) found that herbivores can actually depress soil N by indirectly decelerating $\mathrm{N}$ cycling through decreasing the abundance of plant species with N-rich tissues. The increased soil fertility inside of the exclosures could possibly be explained by differing litter dynamics. The expectation would be that leaf litter with higher $\mathrm{N}$ and lower fibre content would result in faster cycling and improved soil fertility (e.g. Reich et al. 2001). Furthermore, the higher density of woody plants would increase the amount of leaf litter reaching the soil. Thus the higher soil nutrients found inside of the exclosures could possibly be a result of the indirect effect of herbivores, as their removal resulted in higher tree densities. Similarly, fire indirectly affects nitrogen cycling in the KNP by decreasing woody densities (Coetsee, Bond \& February 2010). The similar soil nutrient concentrations found inside and outside of the Nhlangwini exclosure can most likely be attributed to the overall low litter quality and lower densities of herbivores resulting from the nutrient poor granitic soils at this site.

\section{Conclusion}

This study has demonstrated the important role browsers play in savanna dynamics. Browsers directly impact species distributions, densities and population structures by actively selecting for species with favourable traits; this study suggests that species with high leaf $\mathrm{N}$, low total phenolic content and low ADL are favoured. Forty years of no browsing impact was insufficient to allow the recruitment of the dominant species into larger size classes. This supports the idea that cohorts of trees recruit simultaneously, they would however need a break from both herbivory and fire. This study also suggests that browsers have important indirect effects on savanna functioning through their impact on soil nutrient cycling. The magnitude of these indirect effects on soil nutrient cycling appears to depend on inherent soil fertility and climate. The effect of browsers on both vegetation and soils was highest at the low rainfall site with high soil fertility, with a somewhat lesser effect at the higher rainfall basalt site, with almost no effect at the infertile high rainfall granite site. This work highlights the importance of herbivore exclosures in protected areas and some of the challenges faced by researchers when studying browser effects on savanna ecosystems because of the paucity of replicated long-term herbivory exclosures. Future work should identify other possible sites in savannas from around the globe that could be used to corroborate the findings from this study.

\section{Acknowledgements}

This work formed part of the PhD thesis of B.J. Wigley and was made possible thanks to funding from a BDI-PED grant from the French National Centre for Scientific Research, as well as the Andrew W. Mellon Foundation. The authors are hugely grateful to: SANParks, Kruger National Park Scientific Services for allowing the study and logistical support, and Scientific Services game guards for protection in the field. Thanks to two anonymous reviewers for their helpful comments which helped improve this manuscript.

\section{Competing interests}

The authors declare that they have no financial or personal relationships which may have inappropriately influenced them in writing this article.

\section{Authors' contributions}

B.J.W. (Nelson Mandela Metropolitan University) was responsible for the project design, data collection, analyses and reporting of data. C.C. (Nelson Mandela Metropolitan University) assisted in collection of data and reporting, whilst W.J.B. (University of Cape Town) and H.F. (University Claude Bernard Lyon 1) were both PhD supervisors of B.J.W. and made valuable contributions to the refinement of the analyses and the manuscript.

\section{References}

Ammer, C., 1996, 'Impact of ungulates on structure and dynamics of natural regeneration of mixed mountain forests in the Bavarian Alps', Forest Ecology and Management 88, 43-53. http://dx.doi.org/10.1016/S0378-1127(96)03808-X

Anderson, V.J. \& Briske, D.D., 1995, 'Herbivore-induced species replacement in grasslands: Is it driven by herbivory tolerance or avoidance?', Ecological Application 5, 1014-1024. http://dx.doi.org/10.2307/2269351

Ankom Technology, 2010, Procedures, viewed 10 November 2013, from http://www. ankom.com/procedures.aspx

Asner, G.P., Levick, S.R., Kennedy-Bowdoin, T., Knapp, D.E., Emerson, R., Jacobson, J. et al., 2009, 'Large-scale impacts of herbivores on the structural diversity of African avannas', Proceedings of the National Academy of Sciences 106, 4947-4952. http:// dx.doi.org/10.1073/pnas.0810637106, PMid:19258457, PMCid:PMC2650504

Augustine, D.J. \& McNaughton, S.J., 1998, 'Ungulate effects on the functional species composition of plant communities: Herbivore selectivity and plant tolerance', The Journal of Wildlife Management 62, 1165-1183. http://dx.doi.org/10.2307/ 3801981

Augustine, D.J. \& Mcnaughton, S.J., 2004, 'Regulation of shrub dynamics by native browsing ungulates on East African rangeland', Journal of Applied Ecology 41 45-58. http://dx.doi.org/10.1111/j.1365-2664.2004.00864.x

Augustine, D.J. \& McNaughton, S.J., 2006, 'Interactive effects of ungulate herbivores, soil fertility, and variable rainfall on ecosystem processes in a semi-arid savanna', Ecosystems 9, 1242-1256. http://dx.doi.org/10.1007/s10021-005-0020-y

Bergvall, U.A. \& Leimar, O., 2005, 'Plant secondary compounds and the frequency of food types affect food choice by mammalian herbivores', Ecology 86, 2450-2460. http://dx.doi.org/10.1890/04-0978

Bond, W.J. \& Loffell, D., 2001, 'Introduction of giraffe changes acacia distribution in a South African savanna', African Journal of Ecology 39, 286-294. http://dx.doi. org/10.1046/j.1365-2028.2001.00319.x 
Boundja, R.P. \& Midgley, J.J., 2010, 'Patterns of elephant impact on woody plants in the Hluhluwe-Imfolozi park, KwaZulu-Natal, South Africa', African Journal of Ecology 48, 206-214. http://dx.doi.org/10.1111/j.1365-2028.2009.01104.x

Bryant, J.P., Provenza, F.D., Pastor, J., Reichardt, P.B., Clausen, T.P. \& Du Toit, J.T., 1991, 'Interactions between woody plants and browsing mammals mediated by secondary metabolites', Annual Review of Ecology and Systematics 22, 431-446. $\mathrm{http} / / / \mathrm{dx}$.doi.org/10.1146/annurev.es.22.110191.002243

Carmona, D., Lajeunesse, M.J. \& Johnson, M.T., 2011, 'Plant traits that predict resistance to herbivores', Functional Ecology 25, 358-367. http://dx.doi.org/10.1111/j.13652435.2010.01794.x

Codron, D., Lee-Thorp, J.A., Sponheimer, M., Codron, J., De Ruiter, D. \& Brink, J.S. 2007, 'Significance of diet type and diet quality for ecological diversity of African ungulates', Journal of Animal Ecology 76, 526-537. http://dx.doi.org/10.1111/ j.1365-2656.2007.01222.x, PMid:17439469

Coetsee, C., Bond, W.J. \& February, E.C., 2010, 'Frequent fire affects soil nitrogen and carbon in an African savanna by changing woody cover', Oecologia 162, 1027 1034. http://dx.doi.org/10.1007/s00442-009-1490-y, PMid:20213154

Coetzee, B.J., Engelbrecht, A.H., Joubert, S.C.J. \& Retief, P.F., 2008, 'Elephant impact on Sclerocarya caffra trees in Acacia nigrescens tropical plains thornveld of the Kruger National Park', Koedoe 22, 39-60.

Conover, W.J., Johnson, M.E. \& Johnson, M.M., 1981, 'A comparative study of tests for homogeneity of variances, with applications to the outer continental shelf bidding data', Technometrics 23, 351-361. http://dx. doi.org/10.1080/00401706 bidding data', Tech
.1981 .10487680

Cooper, S.M. \& Owen-Smith, N., 1985, 'Condensed tannins deter feeding by browsing ruminants in a South African savanna', Oecologia $67,142-146$. http://dx. doi. ruminants in a South Afrot
org $/ 10.1007 /$ BF00378466

Cornelissen, J.H.C., Lavorel, S., Garnier, E., Diaz, S., Buchmann, N., Gurvich, D.E. et al., 2003, 'A handbook of protocols for standardised and easy measurement of plant functional traits worldwide', Australian Journal of Botany 51, 335-380. http:// dx.doi.org/10.1071/BT02124

Díaz, S., Lavorel, S., McIntyre, S.U.E., Falczuk, V., Casanoves, F., Milchunas, D.G. et al., 2007, 'Plant trait responses to grazing - A global synthesis', Global Change Biology 13, 313-341. http://dx.doi.org/10.1111/j.1365-2486.2006.01288.x

Fornara, D.A. \& Du Toit, J.D., 2007, 'Browsing lawns? Responses of Acacia nigrescen to ungulate browsing in an African savanna', Ecology 88, 200-209. http://dx.do org/10.1890/0012-9658(2007)88[200:BLROAN]2.0.CO;2

Frank, D.A., 2008, 'Ungulate and topographic control of nitrogen: Phosphorus stoichiometry in a temperate grassland; soils, plants and mineralization rates', Oikos 117, 591-601.

Gadd, M.E., 2002, 'The impact of elephants on the marula tree Sclerocarya birrea', African Journal of Ecology 40, 328-336. http://dx.doi.org/10.1046/j.1365-2028. 2002.00385.x

Haslam, E., 1988, 'Plant polyphenols (syn. vegetable tannins) and chemical defense - A reappraisal', Journal of Chemical Ecology 14, 1789-1805. http://dx.doi. org/10.1007/BF01013477

Hattas, D., Stock, W.D., Mabusela, W.T. \& Green, I.R., 2005, 'Phytochemical changes in leaves of subtropical grasses and fynbos shrubs at elevated atmospheric $\mathrm{CO}_{2}$ concentrations', Global and Planetary Change 47, 181-192. http://dx.doi. $\mathrm{org}^{2} / 10.1016 /$ j.gloplacha.2004.10.010

Hattas, D. \& Julkunen-Tiitto, R., 2012, 'The quantification of condensed tannins in African savanna tree species', Phytochemistry Letters 5, 329-334. http://dx.doi. org/10.1016/j.phytol.2012.02.013

Helm, C.V. \& Witkowski, E.T., 2012, 'Continuing decline of a keystone tree species in the Kruger National Park, South Africa', African Journal of Ecology 51(2), 270-279. http://dx.doi.org/10.1111/aje.12032

Huntly, N., 1991, 'Herbivores and the dynamics of communities and ecosystems', Annual Review of Ecology and Systematics 22, 477-503. http://dx.doi.org/10.1146/annurev. es.22.110191.002401

Jachmann, H. \& Croes, T., 1991, 'Effects of browsing by elephants on the Combretum/ Terminalia woodland at the Nazinga Game Ranch, Burkina Faso, West Africa', Biological Conservation 57, 13-24. http://dx.doi.org/10.1016/0006-3207(91)90105-I

Kindt, R. \& Coe, R., 2005, Tree diversity analysis: A manual and software for common statistical methods for ecological and biodiversity studies, World Agroforestry Centre, Nairobi. PMCid:PMC1156951
Kriebitzsch, W.U., Oheimb, G.V., Ellenberg, H., Engelschall, B. \& Heuveldop, J., 2000 'Development of woody plant species in fenced and unfenced plots in deciduous forests on glacial moraine soils in northern Germany', Allgemeine Forst-und Jorests on glacial mor

Levick, S. \& Rogers, K., 2008, 'Patch and species specific responses of savanna woody vegetation to browser exclusion', Biological Conservation 141, 489-498. http:// dx.doi.org/10.1016/j.biocon.2007.11.001

Levick, S.R., Asner, G.P., Kennedy-Bowdoin, T. \& Knapp, D.E., 2009, 'The relative influence of fire and herbivory on savanna three-dimensional vegetation structure', Biological Conservation 142, 1693-1700. http://dx.doi.org/10.1016/j.biocon.2009.03.004

Levick, S.R., Asner, G.P., Kennedy-Bowdoin, T. \& Knapp, D.E., 2010, 'The spatial extent of termite influences on herbivore browsing in an African savanna', Biological Conservation 143, 2462-2467. http://dx.doi.org/10.1016/j.biocon.2010.06.012

Moncrieff, G.R., Chamaillé-Jammes, S., Higgins, S.I., O’Hara, R.B. \& Bond, W.J., 2011, 'Tree allometries reflect a lifetime of herbivory in an African savanna', Ecology 92 2310-2315. http://dx.doi.org/10.1890/11-0230.1, PMid:22352170

O'Connor, T.G., Goodman, P.S. \& Clegg, B., 2007, 'A functional hypothesis of the threat of local extirpation of woody plant species by elephant in Africa', Biological Conservation 136, 329-345. http://dx.doi.org/10.1016/j.biocon.2006.12.014

Owen-Smith, N., 2005, 'Incorporating fundamental laws of biology and physics into population ecology: The metaphysiological approach', Oikos 111, 611-615. http:// population ecology: The metaphysiological app
dx.doi.org/10.1111/j.1600-0706.2005.14603.x

Owen-Smith, N. \& Cooper, S.M., 1987, 'Palatability of woody plants to browsing ruminants in a South African savanna', Ecology 68, 319-331. http://dx.doi.org/ $10.2307 / 1939263$

Penzhorn, B.L., Robbertse, P.J. \& Olivier, M.C., 1974, 'The influence of the African elephant on the vegetation of the Addo Elephant National Park', Koedoe 17, 137-158.

R Project, 2012, 'R: A language and environment for statistical computing', R Foundation for Statistical Computing, Vienna, viewed 10 November 2013, from http://www.rproject.org/

Reich, P.B., Peterson, D.W., Wedin, D.A. \& Wrage, K., 2001, 'Fire and vegetation effects on productivity and nitrogen cycling across a forest-grassland continuum', Ecology 82, 1703-1719.

Ritchie, M.E., Tilman, D. \& Knops, J.M., 1998, 'Herbivore effects on plant and nitrogen dynamics in oak savanna', Ecology 79, 165-177.

Shrader, A.M., Bell, C., Bertolli, L. \& Ward, D., 2011, 'Forest or the trees: At what scale do elephants make foraging decisions?', Acta Oecologica 42, 3-10. http://dx.doi. org/10.1016/j.actao.2011.09.009

Smit, I.P., Smit, C.F., Govender, N., Linde, M.V.D. \& MacFadyen, S., 2012, 'Rainfall, geology and landscape position generate large-scale spatiotemporal fire pattern heterogeneity in an African savanna', Ecography 35, 1-13.

Staver, A.C., Bond, W.J., Stock, W.D., Van Rensburg, S.J. \& Waldram, M.S., 2009 'Browsing and fire interact to suppress tree density in an African savanna', Ecological Applications 19, 1909-1919. http://dx.doi.org/10.1890/08-1907.1, PMid:19831079

Trollope, W.S.W., Trollope, L.A., Biggs, H.C., Pienaar, D. \& Potgieter, A.L.F., 1998, 'Long term changes in the woody vegetation of the Kruger National Park, with special reference to the effects of elephants and fire', Koedoe 41, 103-112.

Van Hees, A.F.M., Kuiters, A.T. \& Slim, P.A., 1996, 'Growth and development of silver birch, pedunculate oak and beech as affected by deer browsing', Forest Ecology and Management 88, 55-63. http://dx.doi.org/10.1016/S0378-1127(96)03809-1

Venter, F.J., Scholes, R.J. \& Eckhardt, H.C., 2003, 'The abiotic template and its associated vegetation pattern', in J.T. du Toit, K.H. Rogers \& H.C. Biggs (eds.), The Kruger experience: Ecology and management of savanna heterogeneity, pp. 83-129, Island Press, Washington, DC.

Wakeling, J.L. \& Bond, W.J., 2007, 'Disturbance and the frequency of root suckering in an invasive savanna shrub, Dichrostachys cinerea', African Journal of Range and an invasive savanna shrub, Dichrostachys cinerea', African Journal of Range
Forage Science 24, 73-76. http://dx.doi.org/10.2989/AJRFS.2007.24.2.3.157

Wessels, D.C.J., Van der Waal, C. \& De Boer, W.F., 2007, 'Induced chemical defences in Colophospermum mopane trees', African Journal of Range and Forage Science 24, 141-147. http://dx.doi.org/10.2989/AJRFS.2007.24.3.4.297

Wigley, B.J., Coetsee, C., Hartshorn, A.S. \& Bond, W.J., 2013, 'What do ecologists miss by not digging deep enough? Insights and methodological guidelines for assessing soil fertility status in ecological studies', Acta Oecologica 51, 17-27. http://dx.doi. org/10.1016/j.actao.2013.05.007 